baryl is often applied for seedling pests like flea beetles, and methamidophos and methyl parathion are often applied for stinkbugs. For these materials, we assume that treatment for other pests was constant during this period. Figure 3 indicates that the use of these materials, as indicated by the number of treatments per acre, declined significantly during the period in Sutter, Yolo, and Colusa counties, where the extensive implementation program was conducted, whereas little change was observed in neighboring Solano and Sacramento counties, where implementation was not actively pursued.

An additional benefit of egg sampling has been the observation that several naturally occurring Trichogramma wasp species, which are egg parasites of the tomato fruitworm, are very important in the Sacramento Valley. Eggs parasitized by these tiny wasps turn black and can easily be identified. Parasitism by Trichogramma spp. reached $80 \%$ or more in mid-August and September (see California Agriculture, January-February, 1990). Demonstration efforts are now being conducted to incorporate the occurrence of these parasites into treatment guidelines. This could result in further reductions in pesticide use for tomato fruitworm.

Development and diffusion of the eggmonitoring program represents the combined efforts of both campus- and countybased research and extension staff, and included both agricultural and social scientists. We believe that this approach provides a model for the process of development, adaptation, evaluation, and education, which is essential in bringing any agricultural innovation into use. This is especially true of this IPM strategy, which substituted information for a routine agronomic practice, preventative pesticide treatment.

Frank G. Zalom is Extension Entomologist and Director, Statewide IPM Project, UC Davis; Craig V. Weakley was Area IPM Advisor, Cooperative Extension, Sutter-Yuba counties, and is Director of IPM, San Tomo Group; Michael P. Hoffmann was StaffResearch Associateat Davis, and is Assistant Professor of Entomology, Cornell University; L. T. Wilson is Professor and Entomologist at UC Davis, presently on leave, and Professor of Entomology, Texas A \& M University; James I. Grieshop is Lecturer in Applied Behavioral Sciences and Community Education Specialist, UC Davis; Gene Miyao was Farm Advisor, Cooperative Extension, Yolo County, and is Research Director, California Tomato Research Institute.

Mike Murray, UC Farm Advisor, provided much guidance in the parts of this study conducted in Colusa County. Many growers and Pest Control Advisers participated in this study, and we are grateful for their assistance and support. This study was sponsored by the Statewide IPM Project.

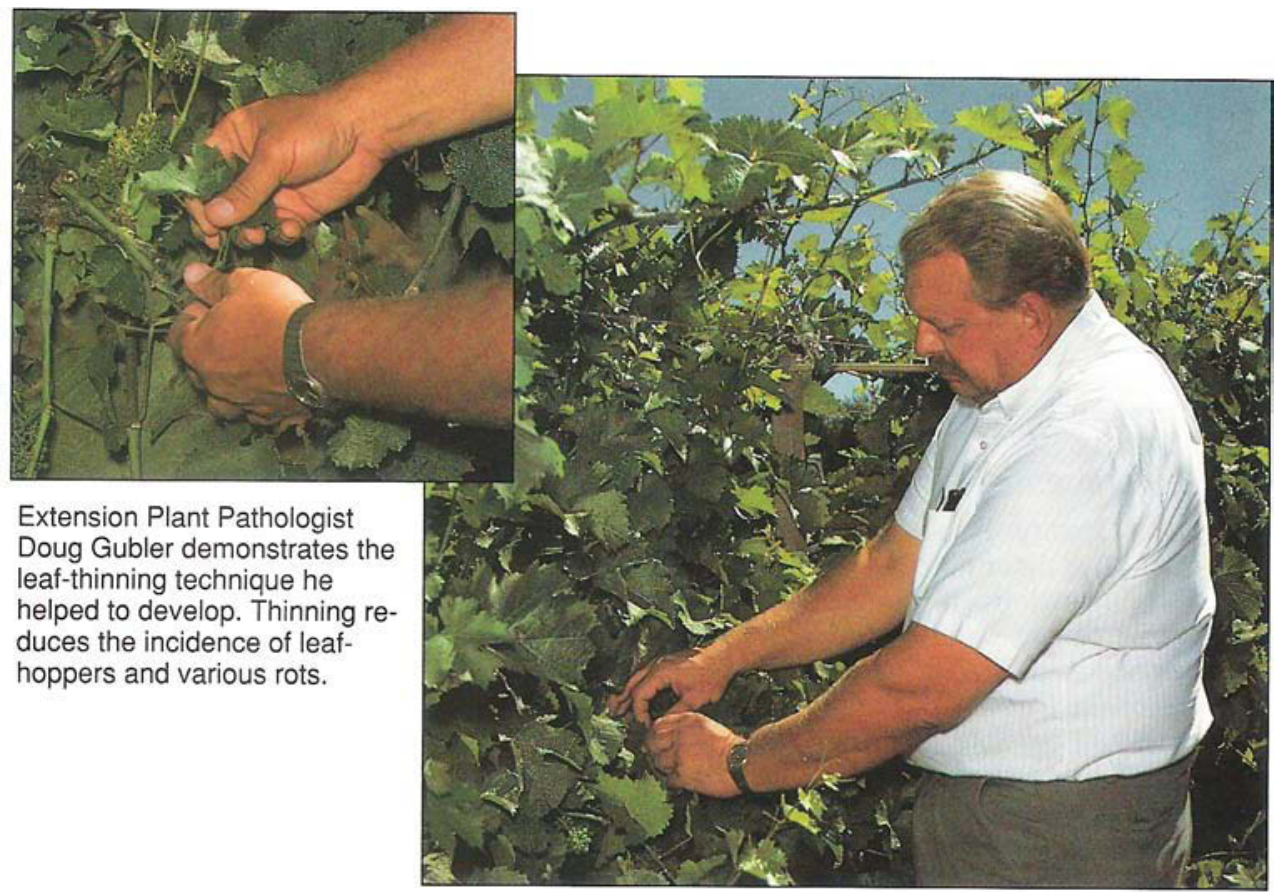

\title{
IPM Leaf removal for pest management in wine grapes
}

\author{
James J. Stapleton \\ W. Douglas Gubler
}

\section{$\square \quad$ William W. Barnett}

- James J. Marois

Leaf removal can effectively manage Botrytis bunch rot and the "summer bunch rot complex" of wine grapes in the San Joaquin Valley and coastal growing areas. The practice may help manage such insect pests as leafhoppers. Producers have adopted leaf removal as a routine cultural practice, especially where high-value, premium varietals are grown.

Grapevine canopy management by leaf removal has been shown to be of significant value for integrated pest management(IPM) of Botrytis bunch rot of grape in coastal growing areas (California Agriculture, MarchApril 1989). Adoption by viticulturists in coastal valleys has been rapid and successful, and has been aided by research data showing trends toward improved grape must and wine quality parameters after the leaf-removal treatment. Improvement of wine quality is of highest importance to producers of premium varietals.

Although most of California's premium varietal wine grape production is concentrated in the coastal areas, the majority of wine grape acreage is located inland, in the San Joaquin Valley. This latter production area is characterized by relatively hot and dry climatic conditions during much of the growing season. A complex of diseases including sour bunch rot, Aspergillus bunch rot, Botrytis bunch rot, and powdery mildew, and arthropod pests such as omnivorous leafroller are responsible for causing bunch rots, resulting in yield and quality losses in Valley growing areas.

Before promoting leaf removal as a standard IPM practice, we needed to test its effects on incidence and severity of bunch rots under the different climatic conditions. Objectives of this research also included determining the effects of leaf removal on a broad range of grape pests, since control of problems other than bunch rots can increase the value of leaf removal over its cost of application.

Results of this study showed that leaf removal can significantly reduce incidence and severity of bunch rots in the San Joaquin Valley, as has been shown previously and confirmed here for coastal areas. Leaf removal also can reduce populations of leafhoppers. We found no consistent effects on grape yield and quality parameters during these studies. 
TABLE 1. Effect of leaf removal and fungicide sprays on severity of Botrytis bunch rot of zinfandel vines, Lake County, 1986

\begin{tabular}{lccccc}
\hline \hline & \multicolumn{5}{c}{ Rot severity (\% rot per cluster) } \\
\cline { 2 - 6 } & $\begin{array}{c}\text { Nonsprayed } \\
\text { control }\end{array}$ & Bloom & $\begin{array}{c}\text { Bloom, } \\
\text { postbloom }\end{array}$ & $\begin{array}{c}\text { Prebloom, } \\
\text { bloom, } \\
\text { postbloom }\end{array}$ & Mean \\
\hline No leaf removal & 10.7 & 14.2 & 11.2 & 8.2 & $11.1 \mathrm{~A}$ \\
Leaf removal & 1.2 & 1.0 & 1.1 & 2.9 & $1.6 \mathrm{~B}$ \\
Mean & 5.9 & 7.6 & 6.1 & 5.6 & -
\end{tabular}

Sprayed with Rovral at $1.5 \mathrm{lbs} /$ acre at the above indicated times.
TABLE 2. Effect of leaf removal and fungicide sprays on incidence of Botrytis bunch rot of zinfandel vines, Lake County, 1986

\begin{tabular}{lccccc}
\hline & \multicolumn{5}{c}{ Rot incidence (\% clusters with rot) } \\
\cline { 2 - 6 } & $\begin{array}{c}\text { Nonsprayed } \\
\text { control }\end{array}$ & Bloom & $\begin{array}{c}\text { Bloom, } \\
\text { postbloom }\end{array}$ & $\begin{array}{c}\text { Prebloom } \\
\text { bloom, } \\
\text { postbloom }\end{array}$ & Mean \\
\hline No leaf removal & 28.2 & 31.1 & 22.7 & 18.7 & $25.2 \mathrm{~A}$ \\
Leaf removal & 5.7 & 5.9 & 3.4 & 6.4 & $5.4 \mathrm{~B}$ \\
Mean & 16.9 & 18.5 & 13.0 & 12.6 & - \\
\hline
\end{tabular}

Sprayed with Rovral at $1.5 \mathrm{lbs} /$ acre at the above indicated times.

\section{Experiments}

Lake County. Two experiments were conducted to determine the effects of timing and interaction with fungicides on the potential of leaf removal to control Botrytis bunch rot. In 1986, a split-plot design was established in a vineyard of Zinfandel, a highly susceptible red variety, with leaf removal being the main plot and fungicide treatments the subplots. The fungicide treatments included control (no fungicide), application at bloom only, application at bloom and 3 weeks postbloom, and application at 2 weeks prebloom, bloom, and 3 weeks postbloom (the standard spray schedulefor this vineyard). Basal leaves were removed from nodes above, opposite, and below (four nodes total) berry clusters of 6 of the 12 vines per plot at fruit set. Each treatment was replicated four times, and disease severity (percent berries diseased per cluster) and incidence (percent clusters with diseased berries) weredetermined at harvest.

Napa County. The effect of the timing and extent of leaf removal on Botrytis bunch rot were examined by removing leaves from Chenin blanc vines 2 weeks before bloom and 2 weeks after bloom (the standard time for leaf removal). At 2 weeks after bloom, leaves were removed from eight nodes rather than the usual four, doubling the number of leaves removed. Disease parameters were determined as described above.

San Joaquin Valley. Test plots were established in 1988 in Stanislaus and Merced County vineyards. The experimental Chenin blanc vineyard in Stanislaus County had not been treated with any pesticides other than sulfur during the three previous years. Two treatments were used: leaf removal and nontreated control, each with 10 replications of 10 vines each. Leaves were removed from bothsides of the vines approximately 2 weeks postbloom.

The Merced County sites included Barbera and Sauvignonblancvineyards. The latter received a postbloom application of thiodan ( $3 \mathrm{lb} / \mathrm{acre}$ ) after leaf removal to control leafhoppers. Treatments were the same as above, except five replications were used, and leaves were removed only from one side of the vines to preserve afternoon shading of berry clusters for sunburn protection.

Leafhopper baseline populations were established at the time of leaf removal, then evaluated six additional times during the season. Bunch rot and yield data were taken at harvest from the center four vines of each replication. Mustquality parametersassayed included degrees Brix, titratableacidity, $\mathrm{pH}$, and anthocyanin (pigment) intensity.

\section{Results}

Lake County. The only significant effect on rot severity (percent rot per cluster) was leaf removal(table1). The fungicides themselves did not seem to reduce disease, except for the incidence (percent clusters with rot) index when three applications were made (table 2). Mean disease incidence was reduced $79 \%$ after leaf removal.

Napa County. Results of the experiment on Chenin blanc were essentially the same as those found in Lake County, the only significant effect being leaf removal. Disease incidence and severity were 48 to $85 \%$ and 57 to $87 \%$ lower, respectively, after removal of

TABLE 3. Effect oftiming and extent of leaf removal on Botrytis bunch rot of Chenin blanc vines at Napa, 1986

\begin{tabular}{|c|c|c|c|}
\hline \multicolumn{2}{|c|}{ Treatment } & \multirow{2}{*}{$\begin{array}{l}\text { Incidence } \\
\text { ( } \% \text { clusters } \\
\text { with rot) }\end{array}$} & \multirow{2}{*}{$\begin{array}{c}\text { Severity } \\
\text { (\% rot per } \\
\text { cluster) }\end{array}$} \\
\hline Tìming & Extent & & \\
\hline $\begin{array}{l}\text { Control } \\
\text { Pre-bloom } \\
\text { Post-bloom } \\
\text { Post-bloom }\end{array}$ & $\begin{array}{l}\text { Basal } 4 \text { nodes } \\
\text { Basal } 4 \text { nodes } \\
\text { Basal } 8 \text { nodes }\end{array}$ & $\begin{array}{r}39.2 \mathrm{a} \\
20.4 \mathrm{~b} \\
12.4 \mathrm{~b} \\
5.9 \mathrm{~b}\end{array}$ & $\begin{array}{l}4.6 \mathrm{a} \\
2.0 \mathrm{~b} \\
1.3 \mathrm{~b} \\
0.6 \mathrm{~b}\end{array}$ \\
\hline
\end{tabular}

TABLE 4. Effect of leaf removal on incidence and severity of bunch rots of wine grapes in the San Joaquin Valley, 1988

\begin{tabular}{|c|c|c|c|c|}
\hline \multirow{2}{*}{$\begin{array}{l}\text { Location, } \\
\text { variety, vine } \\
\text { training, \& } \\
\text { treatment }\end{array}$} & \multicolumn{2}{|c|}{ Botrytis rot* } & \multicolumn{2}{|c|}{ Sour rot* } \\
\hline & Incid. & Sever. & Incid. & Sever. \\
\hline
\end{tabular}

Stanislaus Co.

'Chenin blanc'

Bilateral cordon

$\begin{array}{lllll}\begin{array}{l}\text { Leaf removal } \\ \text { (2-side) }\end{array} & 1.5 \dagger & 0.3 \dagger & 3.0 & 0.3 \ddagger \\ \text { Control } & 13.0 & 3.0 & 8.0 & 2.2\end{array}$

Control 13.0 2.2

Merced Co.

'Barbera'

Bilateral cordon

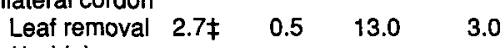

(1-side)

\begin{tabular}{lllll} 
Control & 8.7 & 2.2 & 26.3 & 6.2 \\
\hline
\end{tabular}

- Incidence (\% clusters with rot), severity (\% rot per cluster).

$\dagger$ Value different from that of control at $P=0.01$ according to Student's t-test.

\# Value different from that of control at $P=0.05$ according to Student's t-test. basal leaves. Timing and extent of leaf removal had no effect on rot parameters (table 3).

San Joaquin Valley. At the Stanislaus County test plot, incidence of Botrytis bunch rot was significantly decreased from 13.0 to $1.5 \%$, and severity from 3.0 to $0.3 \%$ in the leaf-removal treatment, as opposed to the nontreated control(table4).Similardecreases in sour rot severity were found, although reductionin rotincidencewas notsignificant, due to high variation among the replications. Low levels of other rots and insect damage also were observed.

At the Merced County Barbera experiment, Botrytis bunch rot incidence was reduced $69 \%$ after leaf removal (table 4 ). No differences in bunch rot severity or sour rot were observed.

In the Stanislaus and Merced County (Sauvignon blanc) vineyards, first-generationleafhopper counts were consistently $30 \%$ to $50 \%$ lower after leaf removal. The reduction in numbers was observed throughout the growing season in the Stanislaus County experiment (fig. 1).

Differences later in the season were not evident in subsequent generations in the Merced County trial, probably because the thiodan application reduced leafhopper populations to very low levels in both treatments. The only significant difference in must quality in the three experiments was an increase in color intensity in the red Barbera variety.

\section{Discussion}

The reductions of Botrytis bunch rot found in coastal areas agreed with previously published reductions. At the Lake County site, leaf removal (main plot) was so effective in reducing rot $(85 \%$ reduction over nontreated control) that there was not enough disease pressure to separate out the effect of fungicide sprays (subplot), or a potential interaction between the two. The inconclusive results obtained with the fungicides could have been due to abnormally hot, dry conditions that existed when the sprays were applied. Other research has shown that the reduction of Botrytis and other bunch rots in vines where leaves were removed appears to be associated with the increase in wind speed within the canopy.

Leaf removal destroys many first-generation nymphs because the majority of the 


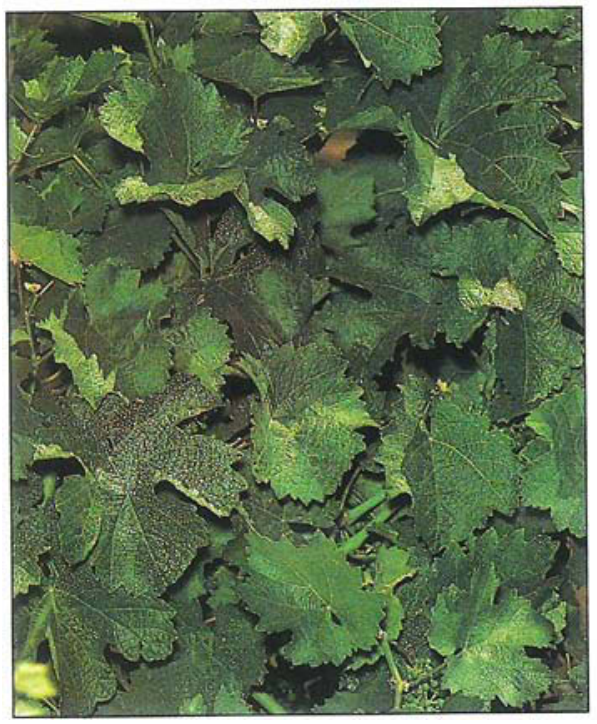

population is present on the removed basal leaves. Although resulting differences in leafhopper populations were not great, they could eliminate the need for first-generation treatment by keeping populations below the recommended treatment threshold of 20 nymphs per leaf. If first-generation treatments can be eliminated, the chances are greatly improved that season-long biological control can be achieved by Anagrus epos, an effective parasite of grape leafhopper.

Previous research has shown that changes in berry composition, and thus wine quality, probably result from increased sunlight exposure. Leaf removal has been found to significantly increase the amount of photosynthetic radiation (PSR) reaching the berries, between 1,100 and 1,300 hours over the entire growing season. Significant negative correlations have been obtained between PSR and $\mathrm{pH}$, malate, and potassium concentration of the berry juice at harvest. The reduction in malate and potassium is considered to be important in producing premium wines.

Data indicating no consistent improvement of must quality from San Joaquin Valley grapes grown with leaf removal, as opposed to those in the Napa Valley, may be explained by climatic differences between

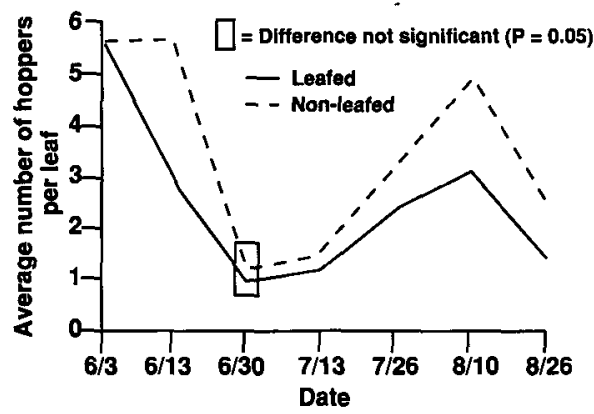

Fig. 1. Leafhopper population levels'were consistently lower after leaf removal at the Stanislaus County site.

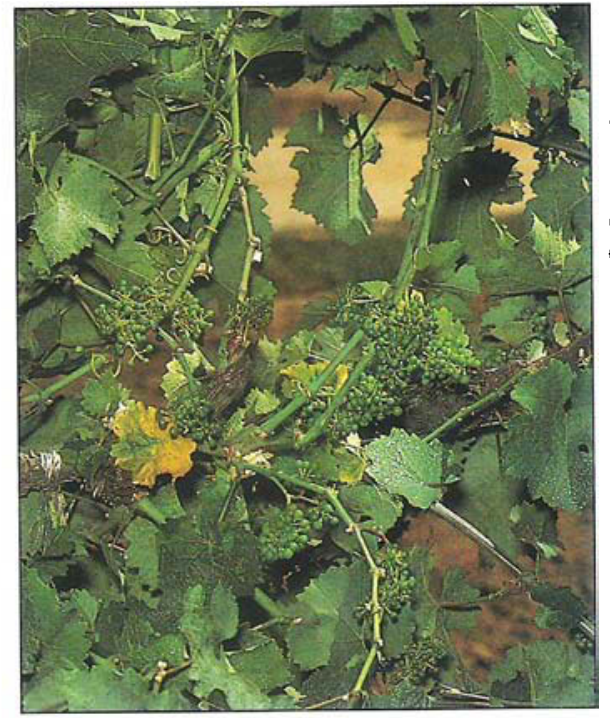

Before thinning (left), air circulation around the leaf-enshrouded grape clusters is insufficient to suppress Botrytis and other rots. After thinning (right), the same area of vine is almost unrecognizable. Rots will not survive on these clusters, and the remaining leaves are sufficient to support fruit development.

the regions. The beneficial change most often seen after leaf removal in the San Joaquin Valley is an increase in color intensity in red grape varieties.

\section{Implementation}

When research was first begun in California in 1984, basal leaf removal was nota common practice in the premium wine growing areas. Some growers had experimented with it butbecause of inappropriate timing or extent of basal leaf removal, few achieved satisfactory results. While the research was being conducted during 1984-1988, the political and regulatory climate toward pesticide use changed tremendously. Many wineries began encouraging their growers to reduce or eliminate sprays to control bunch rot. At the same time, prices and demand for California premium wines continued to grow steadily.

By 1988 , many growers in coastal valley areas were using basal leaf removal as a means of reducing or eliminating fungicides for Botrytis bunch rot, or to improve wine quality. This practice is now often stipulated in contracts between growers and wineries.

Basal leaf removal by hand costs from $\$ 50$ to $\$ 200$ per acre, and by machine, approximately $\$ 20$ per acre. The actual amount for a specific vineyard depends upon labor costs, labor experience, trellis type, pruning method, and vine vigor. These costs are offset by the savings on pesticides, approximately $\$ 20$ to $\$ 40$ per acre for each application depending upon the pesticides used. Many of the coastal area vineyards that now practice only basal leaf removal were applying three bunch rot fungicide sprays per year.

As with any cultural practice, many other aspects of production are affected. If the crop load needs to be adjusted downward, a common practice in many vineyards, growers report that their crews can go faster (thus cheaper) if the leaves have been removed because the clusters are more visible. Also, harvesting by hand is reportedly much faster in vineyards with leaves removed, again because of the greater visibility and accessibility of the clusters.

The increase in degrees brix after basal leaf removal increases the value of the crop, which may be critical in marketability because many wineries have minimum brix tolerances as well as bonuses for values above the minimum. However, some vineyards have adjusted their crop load upward after leaf removal to take advantage of the potential increase in brix, resulting in higher yields at the same brix as obtained without basal leaf removal.

Grapequality in theSan Joaquin Valley is often considered to be lower than that of coastal areas, primarily because of the less favorable, hot and dry climate; consequently, prices received by growers also can be considerably lower. This means that changes in growing practices such as leaf removal may be more difficult to implement in the Valley if only the bunch rot complex and grape must quality are concerned, because growers have less of a profit margin to work with. However, if the benefits of eliminating early season leafhopper pesticide treatments (which often are disruptive to beneficial insects and mites) and faster harvesting with the reduced foliage also are considered, leaf removal may prove to be economically feasible in all grape growing areas.

James J. Stapleton and William W. Barnett are Area IPM Advisors, Cooperative Extension, Stanislaus County and Kearney Agricultural Center, respectively; and James J. Marois is Associate Professor and W. Douglas Gubler is Extension Plant Pathologist, Department of Plant Pathology, UC Davis. This research was supported in part by grants from the Statewide IPM Project. The authors thank grower Ron Berryhill and Stan Grant at E. E J. Gallo Winery Ranches for cooperation in test plots; and Roger Duncan, Dan Hubert, Andy Bledsoe, Mike Vail, and Kerry Waggoner for technical assistance on the project. 